\title{
Embryology and Influence of Temperature and Salinity on Early Development and Survival of Yellowtail Flounder Limanda ferruginea
}

\author{
Geoffrey C. Laurence ${ }^{1}$ and W. Huntting Howell ${ }^{2 *}$ \\ 1 National Marine Fisheries Service, Northeast Fisheries Center, Narragansett Laboratory, Narragansett, Rhode Island 02882, \\ USA \\ ${ }^{2}$ Department of Zoology, University of Rhode Island, Kingston, Rhode Island 02881, USA
}

\begin{abstract}
The purposes of this research were to provide a detailed description of the embryonic development of the yellowtail flounder Limanda ferruginea and to determine the influences of temperature and salinity on developmental rates and survival within the maximal environmental range of these variables $\left(4^{\circ}-18^{\circ} \mathrm{C} ; 28-38 \% \mathrm{~S}\right)$. Embryological categories were described and related to developmental times at different temperatures. This relationship was direct and a series of power function curves were calculated for predictive purposes. Embryo survival to hatching was interactively affected by temperature and salinity. Response surface analyses showed low survival (10-30\%) at low salinities coupled with low and high temperatures, and high survival (70-90\%) at intermediate temperatures and higher salinities. The greatest mortality occurred during gastrulation. Time to $50 \%$ hatching was inversely related to both temperature and salinity. Size at hatching (SL) was influenced by temperature and salinity interaction with larger larvae in the mid salinity range at mid to upper test temperatures. Occurrences of anomalies were relatively low $(<10 \%)$. They were lower at intermediate test temperatures integrated over all salinities and higher at intermediate test salinities integrated over all temperatures. Experimental results are discussed with reference to environmental impact on yellowtail early life stage survival.
\end{abstract}

\section{INTRODUCTION}

Yellowtail flounder, Limanda ferruginea, range along the Atlantic coast of North America from Labrador to Chesapeake Bay (Bigelow and Schroeder 1953). Within this range yellowtail stocks usually inhabit waters shallower than $100 \mathrm{~m}$ and exhibit no major seasonal change in distribution. This causes the fish to be subjected to a wide seasonal range in temperature of from $-1^{\circ}$ to about $16{ }^{\circ} \mathrm{C}$ depending on locale (Pitt, 1970; Colton, 1972). The spawning season is protracted over the entire range from March through August (Colton et al., 1979). As a result, spawning occurs at temperatures varying from $5^{\circ}$ to $12{ }^{\circ} \mathrm{C}(\mathrm{Col}-$ ton, 1972; Colton and Stoddard, 1972).

Yellowtail flounder support fluctuating commercial fisheries over much of their range, particularly in New

\footnotetext{
- Present address: Department of Zoology, University of New Hampshire, Durham, NH 03824, USA.
}

England and adjacent Canada (Royce et al., 1959; Lux, 1964, 1969; Pitt, 1974). Despite this, little is known of their early life-history. Most of the literature on eggs and larvae deals with their temporal and spatial distribution in nature (Royce et al., 1959; Smith et al., 1975, 1978; Able, 1978; Colton et al., 1979), short descriptions allowing for their identification (Hildebrand and Schroeder, 1928; Bigelow and Schroeder, 1953; Colton and Marak, 1969) and fecundity (Howell and Kesler, 1977). The technique developed by Smigielski (1979) to culture yellowtail in the laboratory has facilitated more detailed studies of the early life-history stages (Laurence, 1979; Howell, 1980). Survival of these stages of fishes is generally thought to be a major determinant of eventual year class strength. Embryos and larvae are well known to be sensitive to physical changes in their environment. Temperature and salinity are considered two of the most influential factors for primary marine species ('Marine Ecology', Vol. I). Temperature controls the 
physiology of stenothermous animals by affecting the rate at which biochemical reactions occur and are catalyzed, and salinity plays a major role in electrolyte balance.

The purposes of this research were: (1) to provide a previously lacking description of the embryonic development of the species; (2) to determine the influences of temperature and salinity on development and survival within the maximal tolerable range of these environmental variables. The data presented provide information on embryological development rate which will aid in ageing specimens collected in plankton surveys. Another obvious application will be in the back calculation of spawning biomass in fishery assessment studies (Berrien et al., in press). The optimal combination(s) of temperature and salinity are identified, as well as a feasibility range within which further experimental studies on larval feeding, growth and survival can be conducted.

\section{MATERIALS AND METHODS}

\section{General}

While most of the research was carried out at the National Marine Fisheries Service's Narragansett Lab., the developmental studies were conducted at the Environmental Protection Agency's Research Lab. in Narragansett at a different time. Methods used differed only slightly. In both cases adults were captured by otter trawl in Block Island Sound off Rhode Island and transported live by car to the experimental facilities. They were maintained in either 280001 (NMFS lab.) or in 286 I (EPA lab.) aquaria supplied with a continuous flow of ambient temperature seawater. Adults were allowed to acclimate and ripen naturally under temperature conditions approximating those of the normal spawning period and induced to spawn by hormonal injections (Smigielski, 1979). Eggs were hand stipped and fertilized.

\section{Temperature-Salinity Experiments}

Incubation techniques and experimental design were similar to those reported by Laurence and Rogers (1976). Briefly, embryos in the 2 cell stage were counted and placed in $100 \mathrm{ml}$ incubation containers which contained seawater pre-mixed with artificial salts to the desired salinity and at the temperature which fertilization took place. The incubation containers - static systems with non-sealant plastic tops to prevent evaporation - were placed in temperature control baths. Temperatures were maintained within $\pm 0.25 \mathrm{C}^{\circ}$ of the desired value. Salinities in each incubator were monitored at the beginning and end of the experiment with an overall mean difference of $0.4 \% \mathrm{~S}$ from a given nominal salinity

Two replicates of 25 embryos per incubation container were used in each factor combination. Experimental design was a 2 factor $7 \times 6$ factorial. There were 7 temperatures: $6^{\circ}, 8^{\circ}, 10^{\circ}, 12^{\circ}, 14^{\circ}, 16^{\circ}, 18^{\circ} \mathrm{C}$ and 6 salinities: $28,30,32,34,36,38 \% \mathrm{~S}$

Incubation containers were checked every $24 \mathrm{~h}$ at which time any dead embryos were removed and their developmental stage noted. Upon hatching, prolarvae in each incubation container were counted and measured for standard lengths. Embryos which aborted or were postmature (never hatching) were also enumerated. Any anomalous conditions observed in hatched larvae were recorded. Parameters measured and analyzed from the experimental design included: (1) total and percentage viable hatch and mortality, (2) length at hatching, (3) developmental stage at death, (4) total time to hatch, and (5) percentage of abnormalities.

Statistical analyses included response surface techniques, when appropriate, which have come into vogue for this type of research in recent years (Alderdice, 1972). When the response of an organism to 2 variables is graphically portrayed it assumes the shape of a curved plane. Since maximum or minimum levels of a biological response are often recorded within a specified range of an environmental variable, a second order mathematical expression is appropritate for estimating the relationship between 2 environmental variable levels and an organism's response (Alderdice, 1972). In this research, a linear model of a second degree polynomial was used in the form:

$$
Y=b_{0}+b_{1}(T)+b_{2}(S)+b_{3}\left(T^{2}\right)+b_{4}\left(S^{2}\right)+b_{5}(T \cdot S)
$$

where $Y=$ response variable $; b_{0}=$ a constant $b_{1-5}=$ regression coefficients; $T=$ temperature; $S=$ salinity.

Equation constant and coefficients, as well as analyses of variance calculations, were estimated by a general linear model procedure contained in the Statistical Analyses System (SAS) of the University of Rhode Island Computer Center. Data for plots of the response surfaces were generated iteratively from the above regression equations by noting temperature and salinity levels for response parameter values designated as contour intervals. Temperature and salinity values on response surface contour plots were set to wider values than tested in the experiments to enhance overall interpretation of the form of the responses. Consequently, part of the response contours are extrapolated.

We feel that response surface techniques are not necessarily the best method for interpreting all experimental parameters (i.e. developmental rates which are 
directly dominated by temperature), and more traditional forms of regression and variance analyses (Steel and Torrie, 1960) were employed in these cases.

\section{Developmental Studies}

As noted, developmental studies were conducted independently of the temperature-salinity interaction experiments. Fertilized eggs were divided volumetrically among $46 \mathrm{l}$ black plastic pans containing seawater identical to that in which fertilization had occurred. Twenty-five IU ml $\mathrm{ml}^{-1}$ pencillin and $0.02 \mathrm{mg} \mathrm{ml}^{-1}$ streptomycin were added to each pan as an antibiotic. These pans were placed in temperature regulated water baths, gently aerated, and allowed to equilibrate slowly to the test temperatures. The 4 test temperatures chosen $\left(4^{\circ}, 8^{\circ}, 10^{\circ}, 12^{\circ} \mathrm{C}\right)$ were maintained at $4.5 \pm$ $0.6^{\circ}, 8.7 \pm 0.6^{\circ}, 10.3 \pm 0.5^{\circ}$, and $12.2 \pm 0.6 \mathrm{C}^{\circ}$ (mean \pm $1 \mathrm{SD})$. Dissolved oxygen and salinity ranged from 7.6-8.1 $\mathrm{mg} \mathrm{l}^{-1}$ and 33.0-34.0\% S.

Beginning at fertilization and continuing at regular intervals until yolk-sac absorption, a random sample of embryos or yolk-sac larvae were removed from each temperature treatment, examined for developmental stage, photographed and preserved in $5 \%$ formalin. Drawings were made from photographs of live specimens.

Although development is, of course, a dynamic process, it is traditionally divided for convenience into a series of discrete, easily recognizable categories. These include early cleavages, blastodermal cap, germ ring, embryonic shield, blastopore closure, a 'tail-free' stage, and hatching. A staging classification has been adopted for the present study that incorporates the above mentioned categories into 4 discrete periods. It is similar to that used by Laurence and Rogers (1976) and is:

Stage I - from fertilization to the formation of a complete blastodermal cap;

Stage II - from the formation of a completed blastodermal cap, through the development of the blastocoel and the appearance of the germinal ring, to the formation of the embryonic shield;

Stage III - from the first appearance of the embryonic shield to the closure of the blastopore;

Stage IV - from the closure of the blastopore to hatching

\section{RESULTS}

\section{Descriptive Embryology}

Unfertilized yellowtail eggs are spherical, clear, buoyant and contain no oil droplets. Diameters have been reported as ranging from 0.79 to $1.01 \mathrm{~mm}$ (Colton and Marak, 1969) and from 0.68 to $0.76 \mathrm{~mm}$ (Howell, 1980). Bigelow and Schroeder (1953) describe the surface of the egg as being covered by minute striations, although these were not evident either in this study or to Colton and Marak (1969).

Shortly after fertilization, the cytoplasm of the egg accumulates at the lower pole forming a lenticular shaped area continuous with a very thin layer of cyto-
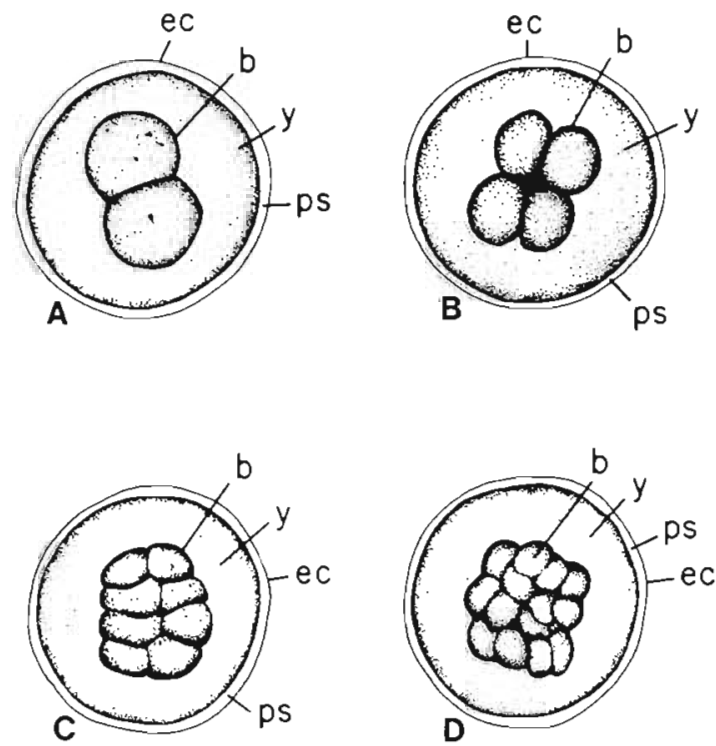

Fig. 1 Limanda ferruginea. Early cleavage stages (A-D) ec: egg capsule; b: blastomere; y: yolk; ps: perivitelline space
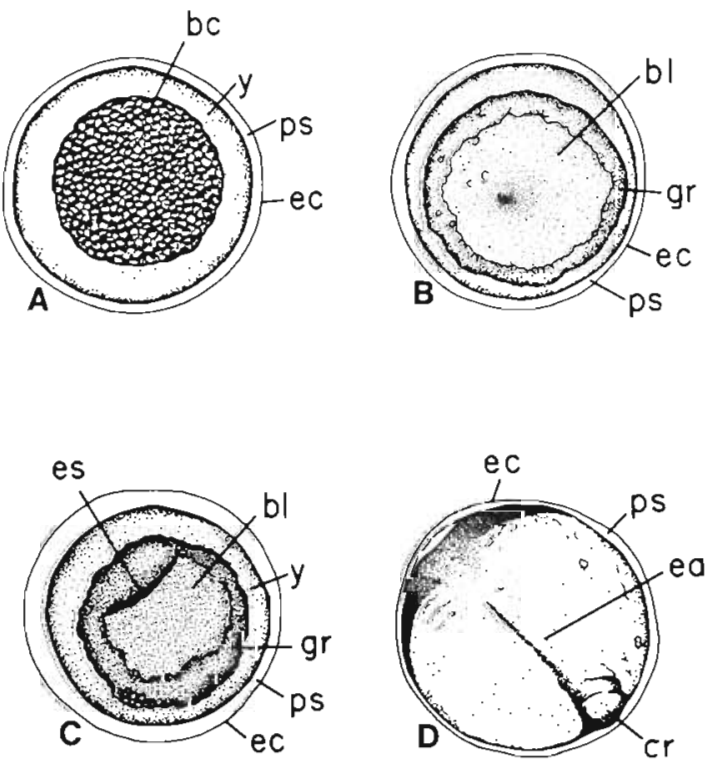

Fig. 2. Limanda ferruginea. Formation of blastula and stages of gastrulation. bc: blastodermal cap; y; yolk; ps: perivitelline space; ec: egg capsule; bl: blastocoele; gr: germ ring; es: embryonic shield; ea: embryonic axis; cr: cephalic region. Stages A-D explained in text 
plasm surrounding the yolk. This area then undergoes a series of mitotic cell divisions which result in a somewhat rounded blastoderm of 16 cells (Fig. 1 A-D). Further cell divisions are difficult to trace because of decreasing size and further enumeration of blastomeres. At the conclusion of the early cell divisions, the blastomeres form a blastodermal cap over the animal pole (Fig. $2 \mathrm{~A}$ ). The central portion of this structure then lifts off the underlying periblast to form the blastocoel which appears as a lightened area in the center of the blastodermal cap. The embryo has now reached the germ-ring stage (Fig. 2B) which marks the beginning of gastrulation. The embryonic shield forms as a tongue of cells protruding from the germ ring into the blastocoel (Fig. 2C), and with continued development the embryonic axis is seen for the first time (Fig. 2D). Coincident with the formation of the embryonic shield, the edges of the blastodermal can continue to grow over the yolk more rapidly in the area opposite the embryonic shield. When the leading edge is approximately equatorial, the embryo has grown in length to extend about half way around the yolk. The cephalic region has become thickened, and Kupffer's vesicle appears near the tail of the embryo. The blastodermal cap continues to progressively cover the yolk via epiboly until only a small portion of the yolk remains uncovered at the blastopore near the caudal region of the embryo. By the time the blastopore stage has been reached, the embryo has grown in length to extend about two thirds of the way around the yolk and the first somites become evident (Fig. 3 A.). At the time of
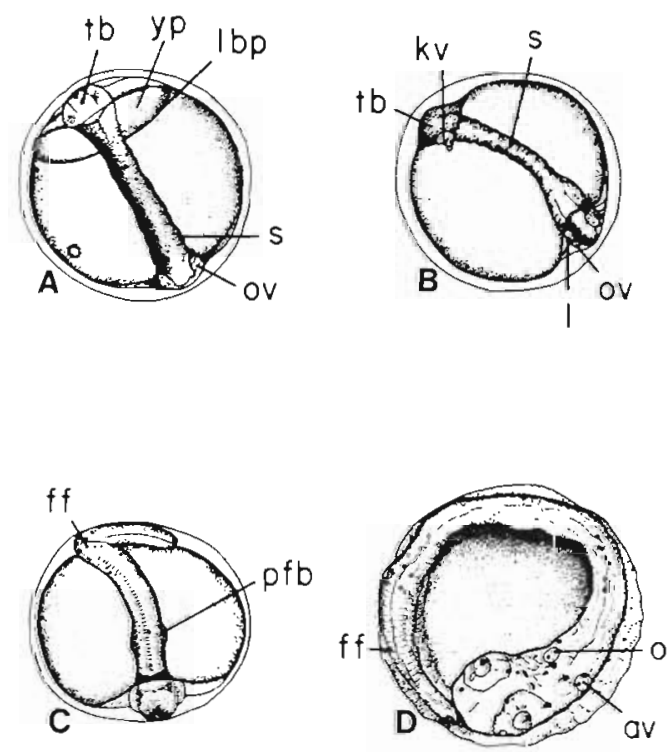

Fig. 3. Limanda ferruginea. Blastopore closure and embryonic stages. tb: tail bud; yp: yolk plug; lbp: lip of blastopore; s: somite; ov: optic vesicle; kv: Kuppfer's vesicle; l: lens; ff: finfold; plb: pectoral fin bud; 0 : otolith; av: auditory vesicle. Stages A-D explained in text blastopore closure optic vesicles have become distinct, the number of somites has increased, and melanophores are obvious on the anterior three-quarters of the ventral surface of the embryo (Fig. 3B). After the closure of the blastopore a number of structures appear in rapid succession as development continues. The auditory capsules become distinct and contain otoliths, pupils develop on the optic vesicles, the heart begins beating, lobes of the brain become distinguishable, pectoral fin buds become obvious, and a low finfold is continuous both dorsally and ventrally. At this time the tail lifts free of the yolk and curves laterally (Fig. 3C). The embryo continues to grow in length until the tail has extended around past the head just prior to hatching (Fig. 3D). Frequent lateral flexures are seen in the embryo at this time.

Hatching occurs by the tail breaking through the chorion and the embryo exiting tail first (Fig. 4). At hatching larvae are between 2.1 and $2.5 \mathrm{~mm}$ long

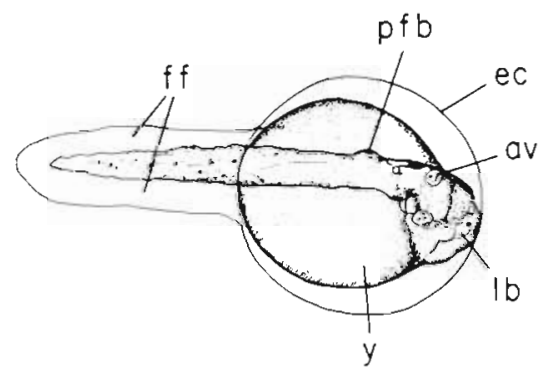

Fig. 4. Limanda ferruginea. Hatching larva. ff: finfold; pfb pertoral fin bud; ec: egg capsule; av: auditory vesicle; lb: lobe of brain; $y$ : yolk

depending on the incubation temperature (Howell, 1980). The eyes are completely unpigmented, oriented ventrally, and are apparently immovable. Pectoral fins are represented as buds only, with no fin rays seen The presumptive mouth is merely an indentation and has no communication with the developing gut. Shortly after hatching melanophores begin to develop in the eyes causing them to appear brown in color. Also at this time the pectoral fin rays begin to develop, and the gut and liver are seen forming (Fig. 5). During the yolk-sac stage the degree of pigmentation increases sharply. A group of 5 or 6 melanophores are seen near the vent which is located just posterior to the yolk-sac. A second group of melanophores is seen in the tail region about midway between the vent and the tip of the tail, and a row of fine pigment spots is apparent in the ventral finfold just below the notochord. These pigment patterns have previously been described by Colton and Marak (1969) as a good diagnostic tool in identifying larval yellowtail. At yolk-sac absorption the gut has developed completely and contains two 


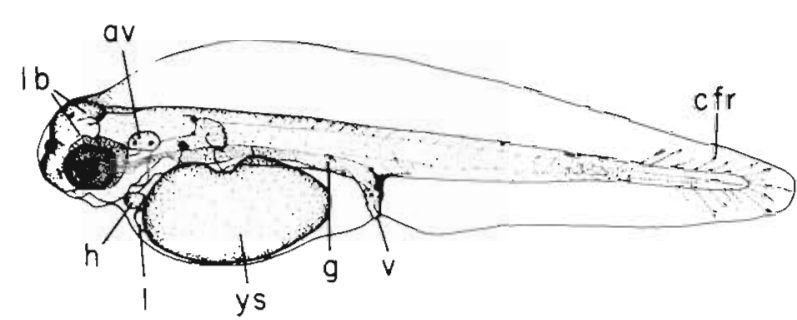

Fig. 5. Limanda ferruginea. Larva. lb: lobe of brain; av: auditory vesicle; cfr caudal fin rays; v: vent; $g$ : gut; ys: yolk sac; l: liver; h: heart

loops. The esophagus and stomach are evident, the mouth and jaw are completely functional, and the vent has opened. The eyes have become darkly pigmented and movable, and the liver has developed into a distinctly 3 -lobed organ. The rate of yolk-sac decrease and time of yolk-sac absorption are dependent on incubation temperature (Howell, 1980).

\section{Temperature and Development Rate}

The effect of temperature on development rates of fishes has been studied extensively (see reviews by Hayes, 1949; Kinne and Kinne, 1962; Blaxter, 1969). Within the thermal tolerance limits of the species, warmer temperatures normally accelerate the developmental process. This is to be expected since metabolic rate increases with temperature in ectotherms. Yellowtail flounder also follow this pattern; a positive relationship being found between incubation temperature and rate of development. Empirically, the relationship is best described by a power curve of the form:

$$
Y=a X^{b}
$$

where $Y=$ development time $(h) ; X=$ incubation temperature $\left({ }^{\circ} \mathrm{C}\right) ; a$ and $b$ calculated constants. Equations are presented graphically in Fig. 6.

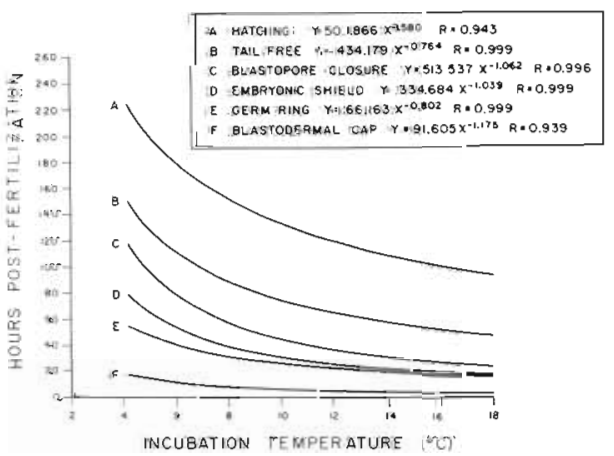

Fig. 6: Limanda ferruginea. Regression relationships of time to designated developmental stages at different temperatures

\section{Temperature-Salinity Experiments}

\section{Embryo Survival}

The grand mean of survival to hatching during incubation over all temperature and salinity combinations was $58.5 \%$ Although this was comparatively good survival, response surface analysis showed that the interactive trend was for lower survival percentages of 10-30\% at lower salinities coupled with high and low test temperatures and for high survival in the order of $70-90 \%$ at intermediate temperatures and higher salinities (Fig. 7).

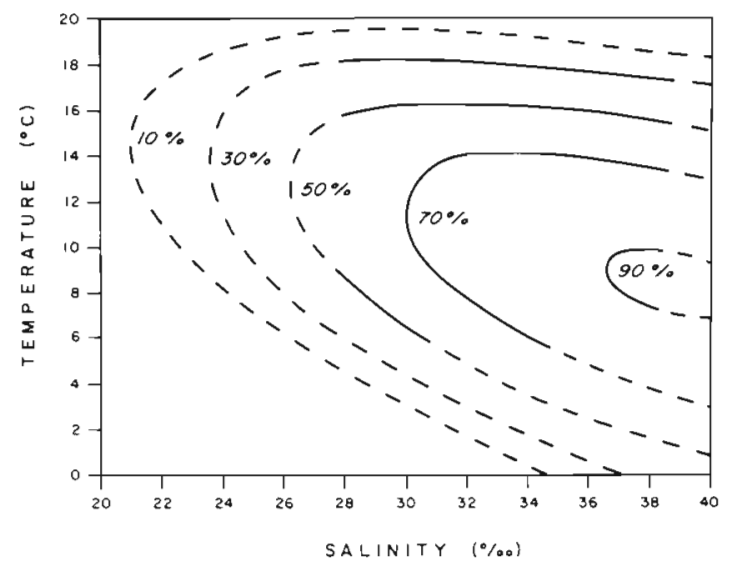

Fig. 7 Limanda ferruginea. Response surface estimates of percent survival at hatching. Dashed lines: extrapolated estimates

A factorial analysis of variance of the influence of temperature, salinity, and developmental stage on mortality percentage showed that temperature and developmental stage accounted for statistically significant variability with developmental stage the more significant of the two $\left(F=40.6>F_{1005\}}=2.2\right.$, d.f. 5,252 for developmental stage and $F=10.4>F_{(0.05)}=2.1$, d.f. 6,252 for temperature). Mortality percentages for selected developmental stages over all temperaturesalinity combinations are presented in Table 1 . Stage II

Table 1. Limanda ferruginea. Mean percent mortality during each developmental stage over all factor combinations. Bracketed means are statistically similar (Duncan's New Multiple Range Test, $\mathrm{P}=0.05$ )

$\left.\begin{array}{|lc|}\hline \begin{array}{c}\text { Developmental } \\ \text { stage }\end{array} & \begin{array}{c}\text { Percent } \\ \text { mortality }\end{array} \\ \hline \text { Stage II } & 18.7 \\ \text { Stage I } & 10.0 \\ \text { Stage III \& IV } & 8.4 \\ \text { Post mature } & 3.3 \\ \text { Partially hatched } & 1.1\end{array}\right\}$


clearly incurred the greatest mortality indicated by the Duncan's New Multiple Range statistical test and was followed by Stage I. This indicated a trend of higher mortality during early development.

Time to $50 \%$ Hatching

Time to $50 \%$ hatching was inversely related to both incubation temperature and salinity. The relationship with temperature was logarithmic, while that of salinity was linear (Fig. 8).

\section{Length at Hatching}

The grand mean of hatching length for yellowtail larvae reared for the temperature-salinity experiments

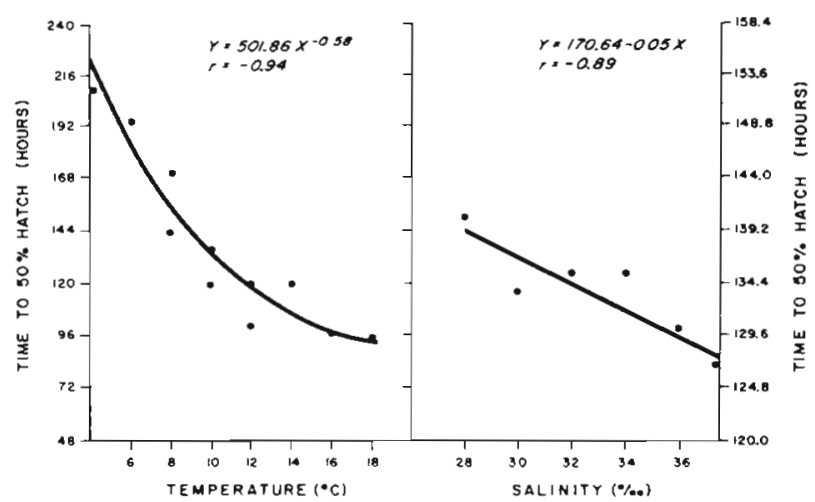

Fig. 8. Limanda ferruginea. Regression relationships between mean times to $50 \%$ hatching at different temperatures integrated over all salinities tested and different salinities integrated over all temperatures

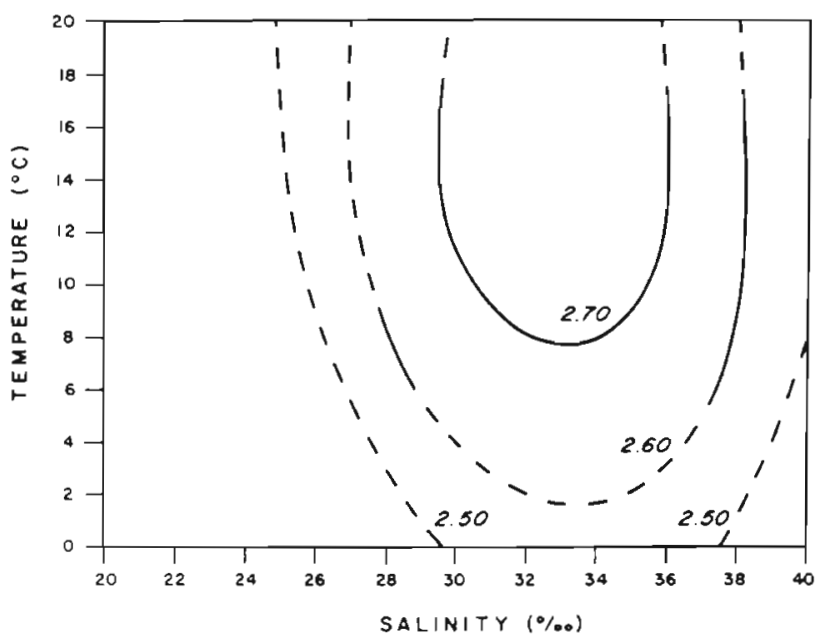

Fig. 9. Limanda ferruginea. Response surface estimates of hatching standard lengths $(\mathrm{mm})$ of larvae at different temperature and salinity combinations. Dashed lines: extrapolated estimates was $2.66 \mathrm{~mm}$ (standard length). Response surface contours demonstrated a trend toward larger larvae in the mid salinity range at mid to upper test temperatures (Fig. 9). The overall range in length in response to factor combinations was not very great, however.

\section{Percentage of Anomalous Conditions}

Occurrence of anomalies were relatively low overall $(<10 \%)$. They were lower at intermediate test temperatures integrated over all salinities and higher at intermediate test salinities integrated over all temperatures (Table 2).

Table 2. Mean percent anomalies of Limanda ferruginea larvae at hatching for temperature over all salinities and salinity over all temperatures tested

\begin{tabular}{|cccc|}
\hline $\begin{array}{c}\text { Temperature } \\
\left({ }^{\circ} \mathrm{C}\right)\end{array}$ & $\begin{array}{c}\text { Mean } \\
\% \\
\text { anomalies }\end{array}$ & $\begin{array}{c}\text { Salinity } \\
(\%)\end{array}$ & $\begin{array}{c}\text { Mean } \\
\% \\
\text { anomalies }\end{array}$ \\
\hline 6.0 & 6.5 & 28.0 & 4.5 \\
8.0 & 6.3 & 30.0 & 5.7 \\
10.0 & 2.7 & 32.0 & 7.2 \\
12.0 & 2.8 & 34.0 & 9.3 \\
14.0 & 3.6 & 36.0 & 1.8 \\
16.0 & 3.1 & 38.0 & 1.2 \\
18.0 & 9.7 & & \\
\hline
\end{tabular}

\section{DISCUSSION}

The results of the experimental studies seem to indicate that yellowtail flounder embryos are quite euryplastic in response to a range of temperature and salinity combinations equalling or exceeding the maximum limits they might encounter in nature. This tendency was indicated by the high survival percentage isopleths of Fig. 7 which maximized along a ridge of mid temperature $\left(8^{\circ}-14^{\circ} \mathrm{C}\right)$ increasing with salinity. The apparent tolerance of yellowtail early life stages to temperature was also noted by Howell (1980) who studied yolk utilization efficiency at different temperatures.

Incubation time, or time to $50 \%$ hatching determined in this study, was strongly influenced by temperature with longer times at lower temperatures (Fig. 8). This fact has been well known for years and summarized for fishes by Blaxter (1969). The importance of this relationship with temperature is not necessarily the tendency, but that the absolute values of hatching times are new information. Incubation time can be an important determinant of survival potential for embryos developing under variable ecological situ- 
ations (i.e. presence of predators, timing with production of prey, potential subjection to pulses of pollutants).

The inverse relationship of hatching time with salinity, although statistically significant, may only be relative within the finite range of the tests and measurements. It is hard to attach any significance in an ecological sense to differences spanning only $0.6 \mathrm{~d}$ $(14 \mathrm{~h})$ over the whole range of factor variability. Changing salinities produce different trends in hatching times (Blaxter, 1969). In general, however, changing salinity appears to have minimal influence on developmental times (Rosenthal and Alderdice, 1976).

As stated previously, the eggs and larvae are most abundant at water temperatures ranging from $5^{\circ}$ to $12^{\circ} \mathrm{C}$. Results based on developmental rates from the regression equations of this research show that time from fertilization to hatching could range from about $197 \mathrm{~h}$ at $5^{\circ} \mathrm{C}$ to only about $118 \mathrm{~h}$ at $12^{\circ} \mathrm{C}$. Therefore embryos incubating at lower temperatures would be exposed to predation for longer periods of time. Lasker (1964) suggests that if predation is a major factor in larval mortality, which has been indirectly demonstrated by Laurence et al. (1979), then time elapsed before development of a well-pigmented eye, which would aid in predator avoidance, could be used as a relative index of survival at different temperatures. It takes the eye of yellowtail larvae more than twice as long to become fully pigmented at $4{ }^{\circ} \mathrm{C}$ (approx. $400 \mathrm{~h}$ ) than at $12{ }^{\circ} \mathrm{C}$ (approx. $195 \mathrm{~h}$ ). In addition to their prolonged exposure to predation, eggs and larvae would also be exposed to potentially unfavorable abiotic conditions for longer periods of time. Colton (1959) observed very high mortality of yellowtail larvae that had drifted into an area approximately $12{ }^{\circ} \mathrm{C}$ warmer than the area to which they were acclimated. The longer the embryonic and prolarval period, and hence pelagic existence, the higher the probability of such catastrophic events occurring.

The higher mortalities associated with the early developmental stages, particularly the blastula and gastrula stages observed in this research, seem to be in general agreement with other experimental studies (Holliday and Jones, 1967; Blaxter, 1969; Alderdice and Forrester, $1971 \mathrm{a}, 1971 \mathrm{~b}$; Braum, 1973; Laurence and Rogers, 1976). The causes for this early mortality, discussed in a review by Rosenthal and Alderdice (1976), are usually 2 types of developmental anatomy problems induced by extemal stress factors. The first involves irregular cell divisions that produce an unusual shaped blastodisc, and the second concerns desynchronization of rates of blastodermal and periblast overgrowth of yolk.

Some ecological significance has been attached to the size of larvae at hatching. It is generally presumed that larger larvae may be more efficient initial predators and have a better chance for growth assuming there is a correlation between hatching size and subsequent size attained at first feeding after further development on endogenous yolk reserves. The statistical tendency in this research for larger larvae to develop at higher temperatures and mid-range salinities is possibly meaningless if one considers that the differences in mean lengths were only in a range of $0.2 \mathrm{~mm}$. This is considerably less than differences in range of lengths noted for other species like cod and haddock (Laurence and Rogers, 1976) and Pacific herring Clupea harengus pallasi (Alderdice and Velsen, 1971). The conclusion is that yellowtail flounder hatching length may not be significantly altered by temperature-salinity changes.

Anomalous conditions or various malformations were rarer for yellowtail in these studies, $10 \%$, compared with $20-35 \%$ for other species studied under experimental conditions (Alderdice and Forrester, 1968, 1971 a; Laurence and Rogers, 1976). The role of malformations or anomalous conditions may or may not influence the survival potential of embryonic and larval fishes. The causes of anomalies are most likely various environmental stresses which affect a biochemical or physiological system which is ultimately manifested as an altered tissue or organ during development, or a genetic deficiency either inherited or the result of mutagenesis due to stress during development.

Sissenwine (1974) noted an inverse correlation between water temperature and yellowtail flounder year class strength. He was unable to substantiate a causal mechanism and concluded that combinations of both physical and biological factors, perhaps acting on the early life stages, might account for this observation.

The results of these studies also do not indicate a direct relationship between temperature and/or salinity and a clearly defined tendency toward maximization of survival within ecologically realistic limits. Yellowtail early life stages, in fact, seem quite viable over a range of physical conditions; a tendency which is further supported by the laboratory experiments of Howell (1980) and the field research of Smith et al. (1978). Therefore, we must deduce that early life survival is most likely affected by synergistic ecological mechanisms which will require more integrated, process-oriented studies.

Acknowledgements. We wish to acknowledge staff members of the NMFS and EPA Laboratories in Narragansett for assistance during the various phases of the research. Special thanks go to Lianne Armstrong, who drafted the analytical figures; Halya Zadoretzky, the biological illustrator of the development figures; and to $M$. P. Sissenwine and $W$. G. Smith, who reviewed the manuscript. 


\section{LITERATURE CITED}

Able, K. W (1978). Ichthyoplankton of the St. Lawrence estuary: Composition, distribution, and abundance. J. Fish. Res. Bd Can. 35: 1518-1531

Alderdice, D. F. (1972). Factor combinations. Responses of marine poikilotherms to environmental factors acting in concert. In: Kinne, O. (ed.) Marıne ecology, Vol. I, Part 3. Wiley, London, pp. 1659-1722

Alderdice, D. F. Forrester, C. R. (1968). Some effects of salinity and temperature on early development and survival of the English sole (Parophrys vetulus). J. Fish. Res. Bd Can. 25: 495-521

Alderdice, D. F., Forrester, C. R. (1971a). Effects of salinity and temperature on embryonic development of the petrale sole (Eopsetta jordani). J. Fish. Res. Bd Can. 28: 727-744

Alderdice, D. F., Forrester, C. R. (1971 b). Effects of salinity, temperature, and dissolved oxygen on early development of the Pacific cod (Gadus macrocephalus). J. Fish. Res. Bd Can. 28: 883-902

Alderdice, D. F., Velsen, F. P. J. (1971). Some effects of salinity and temperature on early development of Pacific herring (Clupea pallasi). J. Fislı. Res. Bd Can. 28: $1545-1562$

Berrien, P. L., Naplin, A., Pennington, M. R. (1n press). Atlantic mackerel, Scomber scombrus, egg production and spawning population estimates for 1977 in the Gulf of Maine, Georges Bank, and Middle Atlantic Bight. In: Lasker, R., Sherman, K. (eds.) Early life history of fish. II. Rapp. P.-v. Réun. Cons. int. Explor Mar 178:

Bigelow, H. B., Schroeder, W C. (1953). Fishes of the Gulf of Maine. Fish. Bull. Fish Wildl. Serv. U.S. 53: 1-577

Blaxter, J. H. S. (1969). Development: Eggs and larvae. In: Hoar, W S., Randall, D. J. (eds.) Fish physiology, Vol. 3, pp. $178-241$

Braum, E. (1973). Einflusse chronischen exogenen Sauerstoffmangels auf die Embryogenese des Herings (Clupea harengus). Neth. J. Sea Res. 7. 363-375

Colton, J. B., Jr (1959). A field observation of mortality of marine fish larvae due to warming. Limnol. Oceanogr 4 (2): 219-222

Colton, J. B., Jr. (1972). Temperature trends and the distribution of groundfish in continental shelf waters, Nova Scotia to Long Island. Fish. Bull. Fish Wildl. Serv. 70: 637-657

Colton, J. B., Jr., Marak, R. R. (1969). Guide for Identifying the common planktonic fish eggs and larvae of continental shelf waters, Cape Sable to Block Island. U.S. Bur Commer Fish., Biol. Lab., Woods Hole, Mass., Lab. Ref. 69-9: $1-43$

Colton, J. B., Jr., Stoddard, R. R. (1972). Average monthly seawater temperatures Nova Scotia to Long Island. Ser. Allas Mar Environ. Am. Geogr Soc. Folio 22

Colton, J. B., Jr., Smith, W G., Kendall, A. W. Jr., Bermen, P. L., Fahay, M. P. (1979). Principal spawning areas and times of marine fishes. Cape Sable to Cape Hatteras. Fish. Bull. U.S. 76: 911-915

Hayes, F. R. (1949). The growth, general chemistry, and tem. perature relations of salmonid eggs. Q. Rev. Biol. 24: 281-308

Hildebrand, S. F., Srhroeder, W. C. (1928). Fishes of Chesapeake Bay. Bull. U.S. Bur Fish. 43: 1-366

Holliday, F. C. T., Jones, M. P. (1967). Some effects of salinity on the developing eggs and larvae of the plaice Pleuronectes platessa. J. mar biol. Ass. U. K. 47. 39-48
Howell, W. H. (1980). The effect of incubation temperature on growth, yolk utilization rate and yolk utllization efficiency in yeliowtail flounder (Limanda ferruginea) embryos and prolarvae. Fish. Bull. U.S. 78: 731-739

Howell, W. H., Kesler, D. H. (1977). Fecundity of the Southern New England stock of yellowtal flounder, Limanda ferruginea. Fish. Bull. U.S. 75: 877-880

Kinne, O., Kinne, E. M. (1962). Rates of development in embryos of a cyprinodont fish exposed to different temperature-salinity-oxygen combinations. Can. J. Zool. 40: $231-253$

Lasker, R. (1964). An experimental study on the effect of temperature on the incubation time, development, and growth of Pacifuc sardine embryos and larvae. Copeia 1964 (2): 399-405

Laurence, G. C., Rogers, C. A. (1976). Effects of temperature and salinity on comparative embryo development and mortality of Atlantıc cod (Gadus morhua L.) and haddock (Melanogrammus aeglefinus L.). J Cons. int. Explor Mer 36: $220-228$

Laurence, G. C. (1979). Larval length-weight relations for seven species of Northwest Atlantic fishes reared in the laboratory. Fish. Bull. U.S. 76: 890-895

Laurence, G. C., Halavik, T A., Burns, B. R., Smigielski, A.S (1979). An environmental chamber for monitoring in situ' growth and survival of larval fishes. Trans. Am. Fish. Soc 108: $197-203$

Lux, F. E. (1964). Landings, fishing effort, and apparent abundance in the yellowtail flounder fishery. Res. Bull. int. Comm. Northw. Atlant. Fish. No. 1: 5-21

Lux, F. E. (1969). Landings per unit of effort, age composition and total mortality of yellowtail flounder, Limanda ferruginea (Storer), off New England. Res. Bull, int. Comm. Northw. Atlant. Fish. No. 6: 47-52

Pitt, T. K. (1970). Distribution, abundance, and spawning of yellowtail flounders, Limanda ferruginea, in the Newfoundland area of the Northwest Atlantic. J. Fish. Res. Bd Can. 27: 2261-2271

Pitt, T K. (1974). Age composition and growth of yellowtail flounder (Limanda ferruginea, from the Grand Bank. J. Fish. Res. Bd Can. 31: 1800-1802

Rosenthal, H., Alderdice, D. F. (1976). Sublethal effects of environmental stressors, natural and pollutional, on marine fish eggs and larvae. J. Fish. Res. Bd Can. 33 $2047-2065$

Royce, W. F., Buller, R. J., Premetz, E. D. (1959). Decline of the yellowtall flounder (Limanda ferruginea) off New England. Fish. Bull. Fish Wildl. Serv. U.S. 59: 169-267

Sissenwine, M. P. (1974). Variability in recruitment and equilibrium catch of the southern New England yellowtail flounder fishery. J. Cons. int. Explor Mer 36 (1): 15-26

Smigielski, A. S. (1979). Induced spawning and larval rearing of the yellowtail flounder, Limanda ferruginea. Fish. Bull U.S. 76: 931-936

Smith. W G., Sibunka, J. D., Wells, A. (1975). Seasonal distributions of larval flatfishes (Pleuronectiformes) on the contmental shelf between Cape Cod, Mass., and Cape Lookout, N. C., 1965-66. NOAA Tech. Rep. NMFS SSRF691.

Sinith, W. G., Sibunka, J. D., Wells, A. (1978). Diel movements of yellowtall flounder, Limanda ferruginea, determined from discrete depth sampling. Fish. Bull. U.S. 76: 167-178

Steel, R. G. E., Torrie, J. H. (1960). Principles and procedures of statistics, McGraw-Hill Book Co., Inc, New York, N.Y. 